\title{
高位病変に対する内䅡動脈内膜剝離
}

一どのレベルまでの展開が可能か一

\author{
大森 一美 ${ }^{1}$, 神吉しづか ${ }^{1}$, 熊谷 哲也 ${ }^{1}$ \\ 福島 孝徳 ${ }^{2}$, 真田 寧皓 ${ }^{3}$
}

\section{Extended Approach of Carotid Endarterectomy for High Cervical Lesions}

Kazumi Ohmori, M.D., ${ }^{1}$ Shiduka KamiYoshi, M.D., ${ }^{1}$ Tetsuya Kumagai, M.D., ${ }^{1}$ Takanori Fukushima, M.D., D.M.Sc., ${ }^{2}$ and Yasuhiro SANADA, M.D. ${ }^{3}$

${ }^{1}$ Department of Neurosurgery, Cerebrovascular Center, Fuchu Hospital, Izumi, Osaka, Japan, ${ }^{2}$ Department of Neurosurgery, West Virginia University, WV, USA, and ${ }^{3}$ Department of Neurosurgery, Kinki University Hospital, Osakasayama, Osaka, Japan

\author{
Key words: \\ - carotid endarterectomy \\ - high cervical lesions \\ - deep cervical fascia
}

Surg Cereb Stroke (Jpn) 41: 89-95, 2013

\section{はじめに}

頚動脈内膜剝離術 (CEA: carotid endarterectomy) は頚 動脈狭窄病変に対して 1 つの有効な治療である ${ }^{1167) 79)}$. 近 年ステント留置術(CAS)がさかんに行われているが，症 例に応じては腎不全などの造影剤使用困難ケースや, 硬化
病変の性状や形状により, CAS が困難なケースも存在し, その際，高位病変などの症例では，CEA も困難であるた め, 治療に難渋することもしばしば遭遇する。

CEA における手術手技上の最大のポイントは内頝動脈 末梢端のプラーク断端の処置であり，このためには内頝動 脈を末梢側に向けて，十分に剥離・確保する必要がある.

${ }^{1}$ 社会医療法人生長会 府中病院 脳外科・脳血管センター, ${ }^{2}$ West Virginia 大学 脳神経外科, ${ }^{3}$ 近畿大学医学部附属病院 脳神経外科 (受稿日 2012.12.22) (脱稿日 2012.11.12) 〔連絡先：５594-0076 大阪府和泉市肥子町 1-10-17 府中病院 脳外科・脳血管セン夕ー 大森 一美] [Address correspondence: Kazumi OhmoRi, M.D., Department of Neurosurgery, Cerebrovascular Center, Fuchu Hospital, 1-10-17 Hiko-cho, Izumi, Osaka 594-0076, Japan] 


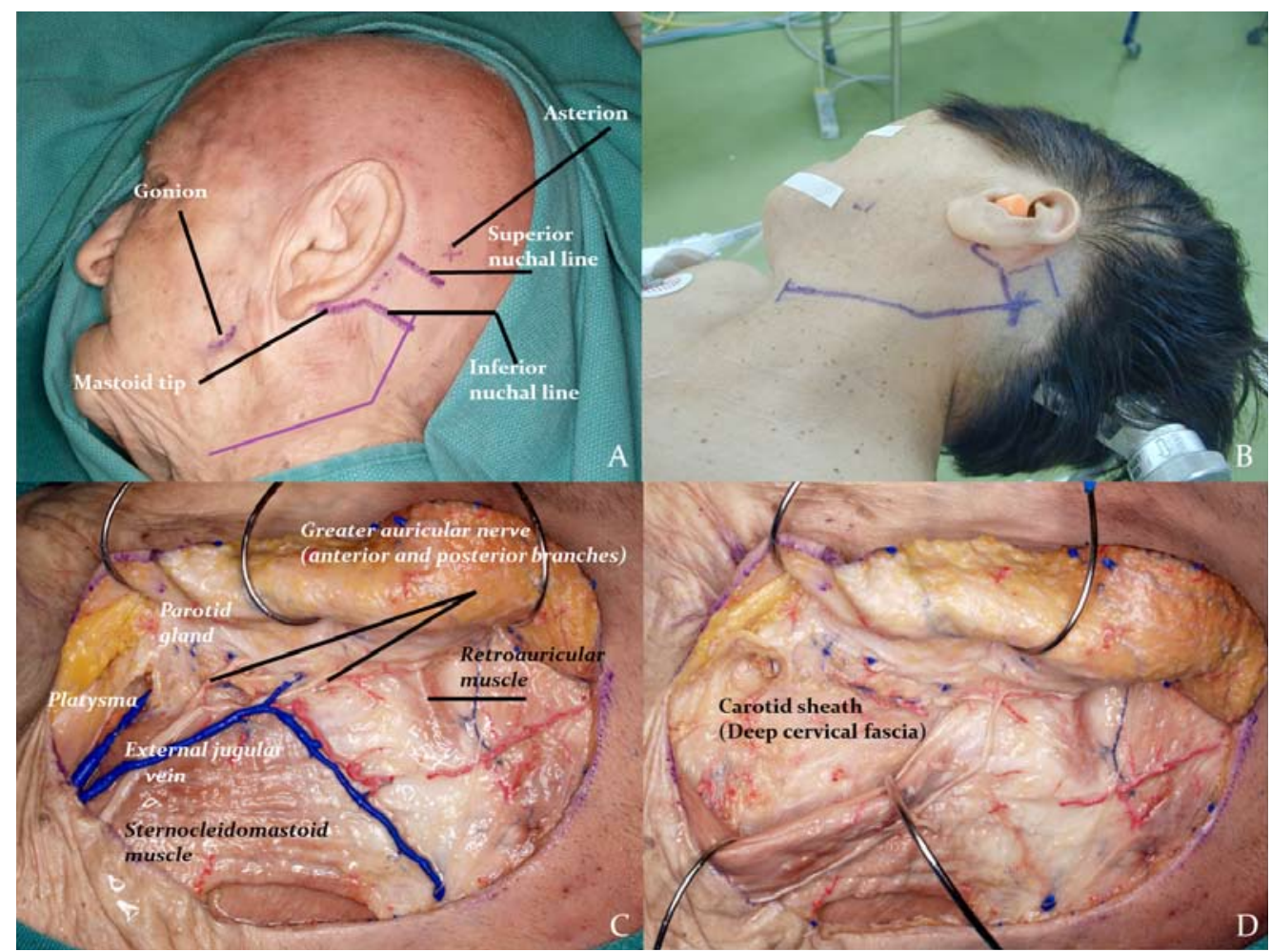

Fig. 1 Operation landmarks.

A: Surface landmarks. B: Surgical position and skin incision. C: Exposure of subcutaneous tissues. D: Exposure of the deep cervical fascia.

CEA における手術困難の目安となる高位病変とは, 頚動 脈プラークの内頝動脈末梢側が乳様突起先端部と下顎角を 結ぶライン (mastoidmandibular line: M-M line)を越える もの，あるいは第 2 頚椎体に及ぶ症例とされている

高位病変に対する CEA では，これまでに経鼻挿管や頚 部の過伸展など，さまざまな工夫が報告されているが2)4 12)，われわれは，従来の方法より後方からアプローチし， かつ層ごとに dissectionすることで，C1 レベルを超え， 頚動脈管入口部までの展開が可能と考えている. 今回，一 部 cadaver dissectionの写真を用いて, 層ごとの解剖を提 示しながら, 術式の詳細と実際の症例について, 文献的考 察を加え，紹介・報告する.

\section{Cadaver Dissection}

\section{1. 皮弁形成 (Fig. 1A)}

表皮・真皮までの層で皮弁を形成し翻転すると，浅䅡筋 膜の層が露出されるが, 肉眼ではなかなか確認することが 困難なほど退化してしまっていることが多い，そのため実 際には広頚筋，上方では胸鎖乳突筋を包む深頚筋膜 (浅葉) が露出される，広頚筋が存在するよりも上方で，深頚筋膜 浅葉下を走行する大耳介神経を損傷しないよう注意を要す る。

90 脳卒中の外科 41: 2013
広頝筋は, この手術において切離される唯一の筋肉であ り，それを行い展開すると，広く術野に胸鎖乳突筋および それを包む深澒筋膜が露出される.

\section{2. 深頚筋膜の剝離}

胸鎖乳突筋と深澒筋膜を十分に剥離することが，この手 術におけるなによりのポイントと考えている(Fig. 1C). 深䅡筋膜浅葉は上方で後頭骨骨膜と癒合しているため, 固 く組織と癒着しているが，丁寧に操作をすれば，胸鎖乳突 筋の付着部である乳様突起まで十分に剥離可能である. こ の段階で胸鎖乳突筋前縁の可動性が高まり (Fig. 1D), C1 の横突起を容易に露出させることが可能となる.

\section{3. 頚動脈鞘切開}

深颍筋膜の一部からなる頚動脈鞘 (Fig. 2A) を切開し, 展開していく．この時点で C1 レベルまで容易に達してい ることがわかる (Fig. 2B). 内頝静脈およびその内外側(症 例により相違)を走行する副神経に注意を要する.

\section{4. 頚動脈鞘の展開}

頚動脈鞘を展開すると, 総澒動脈から内澒動脈がひろく 露出される $($ Fig. 2C). 実際の手術手技上のポイントとし 

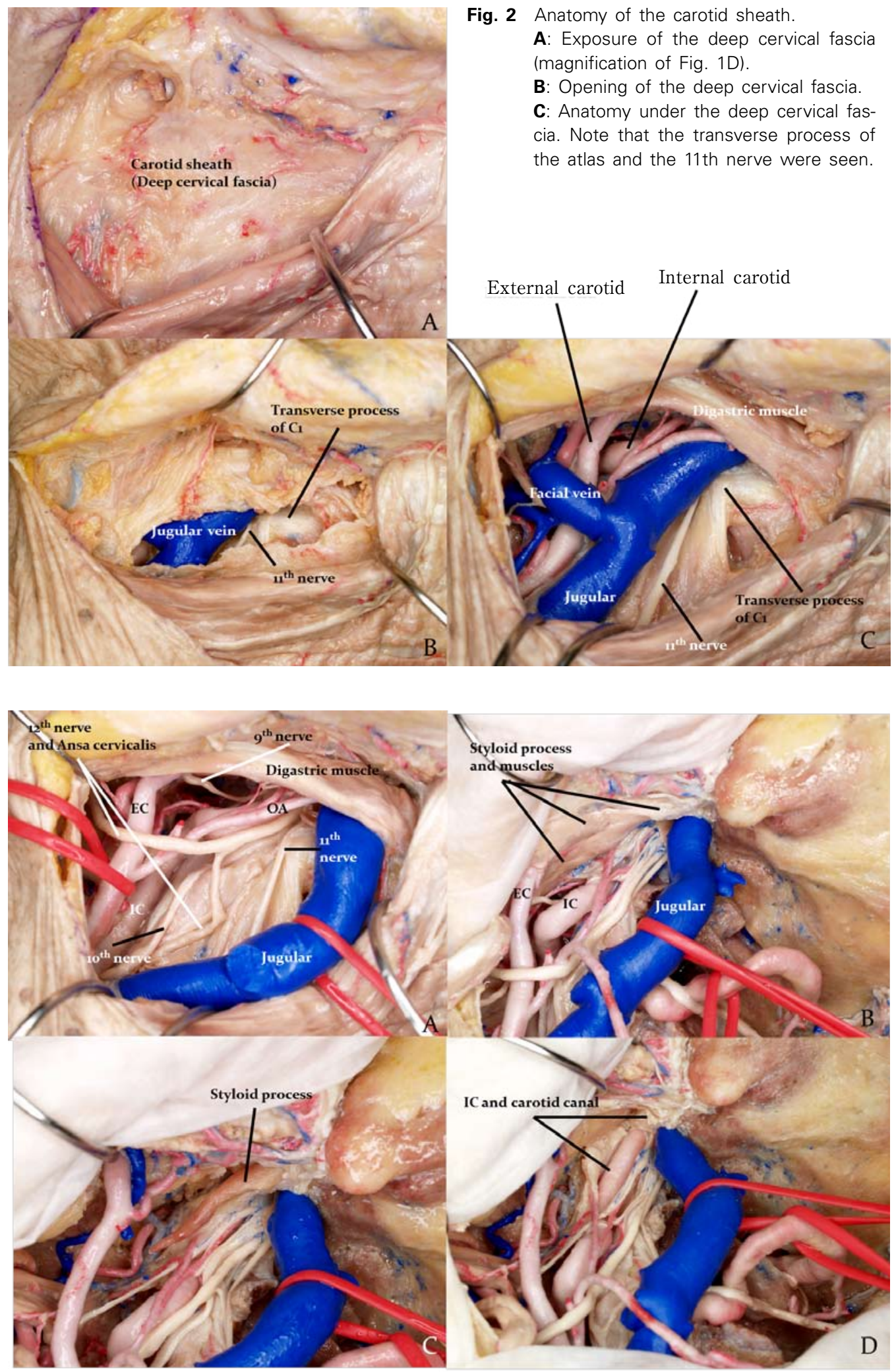

Fig. 3 Exposure of the high cervical portion of the internal carotid artery.

A: High cervical portion of the IC was exposed after retraction of the internal jugular vein. B: Styloid process and muscles were exposed after dissection of the posterior cervical muscles. C: Exposure of the styloid process. D: Removal of the styloid process. Note that the orifice of the carotid canal was seen. 


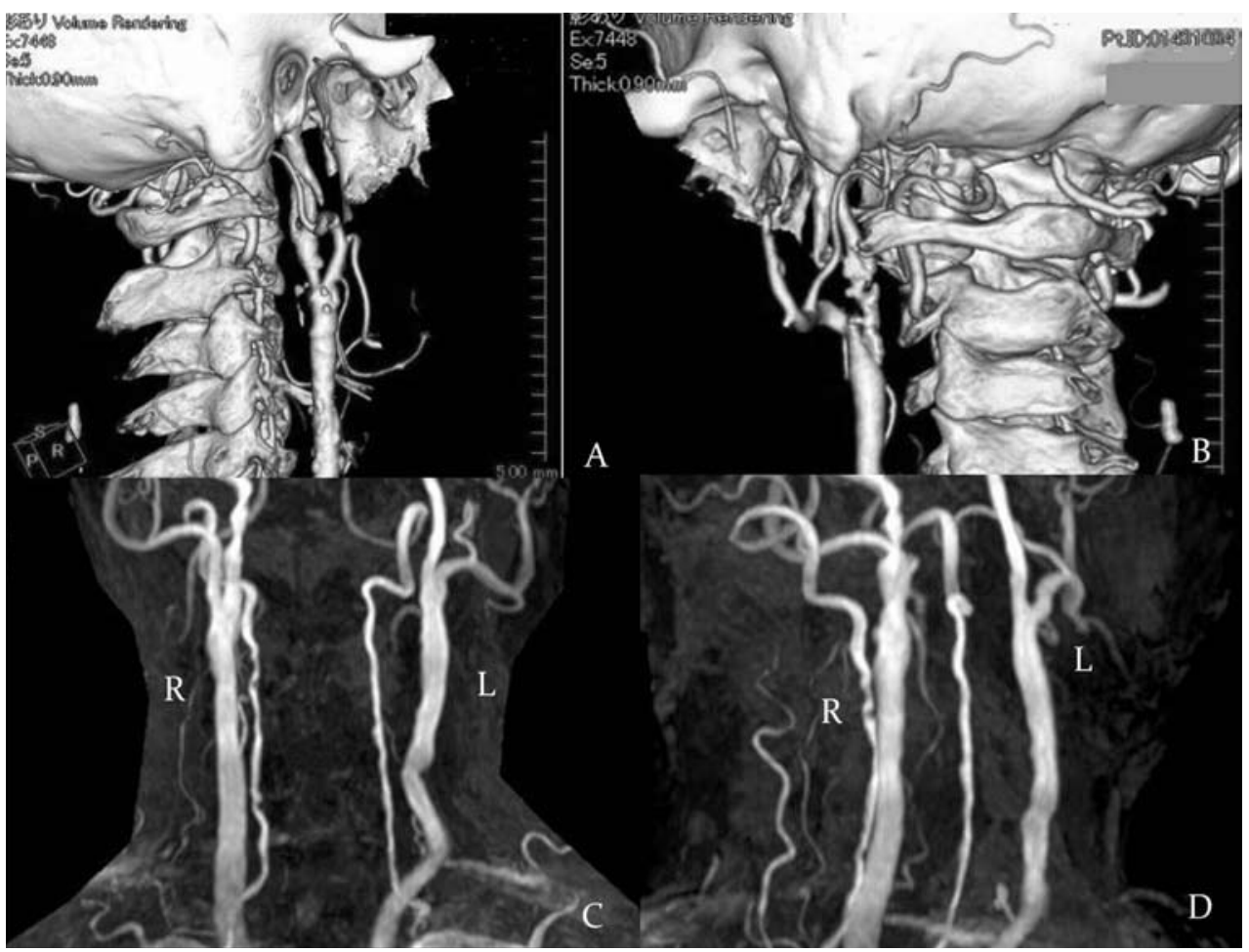

Fig. 4 Pre- and postoperative images of the representative case.

A: Preoperative 3D-CT angiography of the right carotid artery.

B: Preoperative 3D-CT angiography of the left carotid artery.

C, D: Postoperative MR angiography. Note that the stenosis of It. IC was improved.

ては, 顔面静脈のネットワークが発達しているため鈍的操 作を避けること，また，舌下神経の直接損傷を防ぐべく， 䅡神経ワナを十分下方で確保し, それを上方に辿るように アプローチしている.

また，頚動脈管入口部ではその外側に存在する styloid process およびそれに付着する筋群 (stylohyoid, stylopharyngeus, styloglossus muscles)の処理により, 同部位ま で内頝動脈を露出させることが可能となる(Fig. 3A，B， C， and $\mathbf{D})$.

\section{症例}

69 歳女性. 当院循環器科で高血圧, 狭心症, 腎不全に て内服加療中であった．全体的に動脈硬化が強く予想され たため頭䅡部血管精査施行. 両側内頚動脈狭窄指摘され, 当科紹介となった。当科初診時, 神経学的異常所見を認め ず，石灰化を伴っていたため詳細評価困難ではあったが 3D-CT 上, 右内頚動脈に約 60\%, 左内頚動脈に $90 \%$ 以上 の狭窄を認めた (Fig. 4A，B，C， and D). 無症候性病変で はあったが高度狭窄であること, また, 当科初診時の血液 学的検查上, BUN $55.0 \mathrm{mg} / \mathrm{dl}$, Cre $3.00 \mathrm{mg} / \mathrm{dl}$ であり, 血管内治療は困難と判断したことから，CEAを施行する こととなった.

\section{手術手技}

体位は仰臥位で，頭䅡部を右側に約 $60^{\circ}$ 回旋させた状態 とし, 肩枕を入れ, 上体を傾斜させたのち, さらに術野を できるだけ一平面として大きく確保する目的で, 澒部も右 側に伸展，下顎を挙上させる，ついで，サージカルテープ を使用し，左肩を尾側へわずかに率引しておき，頭部を馬 蹄型ヘッドレストで固定したのち, 上体全体を約 $20^{\circ}$ 挙上 させ，逆ジャックナイフ体位とする。

䅡部解に沿って約 $10 \mathrm{~cm}$ の切開線を置き, それを乳様 突起後方にまで延長させる 'L 字型” の切開線を整容上の 理由から用いることが多い(Fig. 1B). 表皮・真皮を切開 し, 皮下脂肪層を露出, バイポーラ電気メスで止血してい くが, この際, 無血術野を得るべく, 丹念に止血を行って いくことが肝要である.

皮下で皮弁を翻転したのち, 広頚筋を露出し, モノポー ラ電気メスで同筋を切開すると, 筋下層に脂肪層をみるこ とが多い。これを胸鎖乳突筋が露出するまで分けていく と, その外側に外頚静脈抢よび, 広䅡筋上端よりさらに上 方を走行する大耳介神経が確認できる. 大耳介神経は, 広 頝筋より上方で深頚筋膜外側の脂肪層内を走行しており, 術操作の際には, 損傷させないよう注意が必要である. 


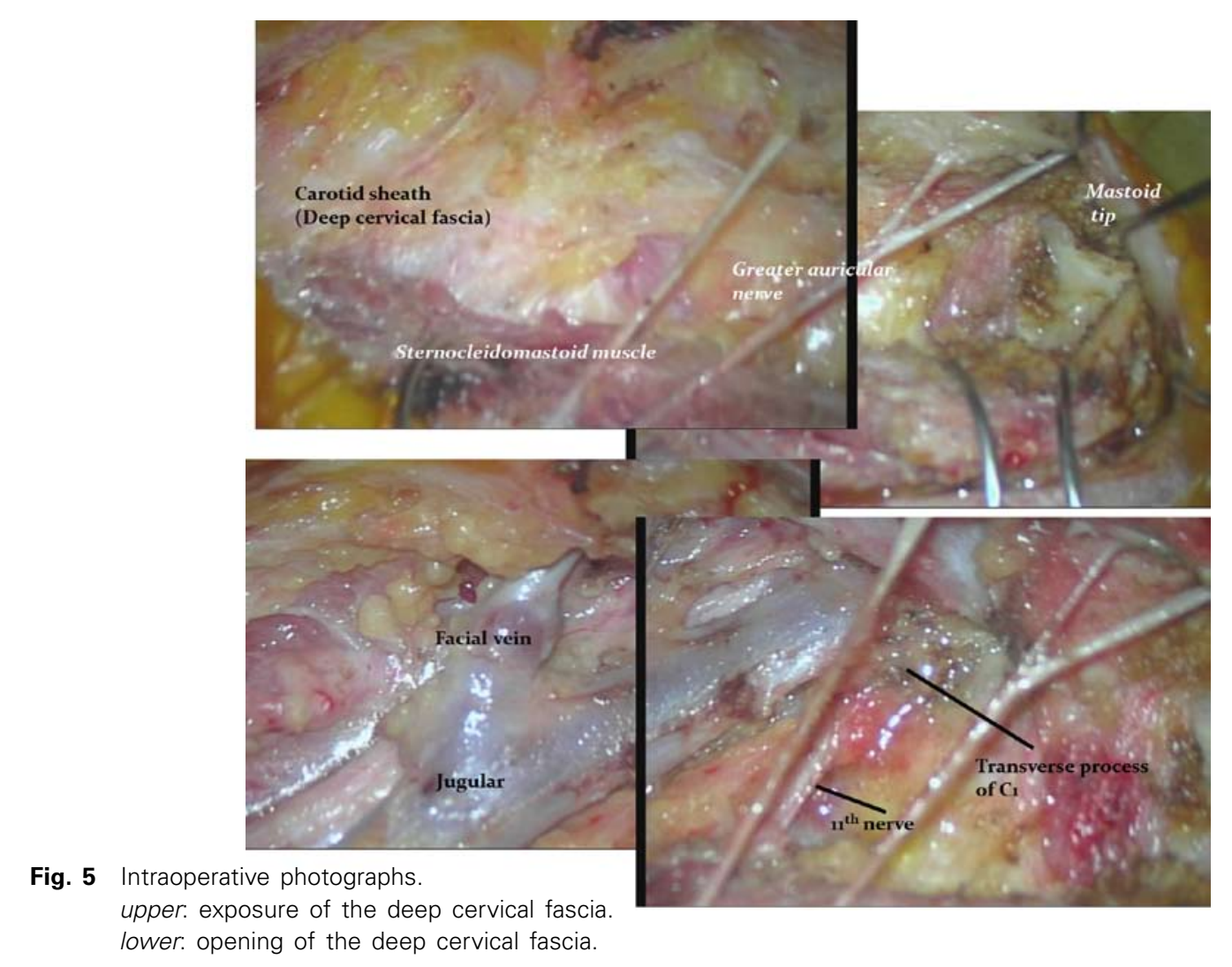

胸鎖乳突筋前縁およびその表層を覆う深澒筋膜を確認 し，これを剥離したのち，筇膜を前方 (耳下腺側)に牽引， 胸鎖乳突筋の前縁を露出する.ささらにその後, 胸鎖乳突筋 と胸鎖乳突筋前縁に位置する深澒筋膜を剝離し, 胸鎖乳突 筋を後方に牽引するが，このとき， C1 横突起が触知確認 できるまで上方を十分に展開していくことが重要である. 展開後, 筋膜ごと前方に牽引することで, 耳下腺掞よび顔 面神経がこの筋膜で覆われることとなり, 頚動脈鞘内外の 区別がしやすく，これら周囲の主要構造物の術操作による 損傷を極力防ぐことができる.

胸鎖乳突筋の上方付着部は乳様突起であるため, 胸鎖乳 突筋の前縁で付着部に向かって筋膜を上方へ剝離していく ことにより，C1 レベルょりもさらに上方まで術野を展開 することが可能となる. 上方洜離に関しては, 下方に比す と, 筋膜付着が格段に強固であり，展開するのに難渋する ことが懸念されるが, 丁寧に剝離していけば, 特に困難な 操作ではないと考えている. これは, 高位病変で安全な術 野を得るためのアプローチに抒いて, われわれが最も重要 なポイントとしている操作である(Fig. 5 upper).

さらに胸鎖乳突筋を後方へ牽引すると, 内䅡静脈が容易 に透見されるが，このように後方から臨むアプローチに よって, 下顎角が術野の妨げとなるのを極力抑えることが でき，より広い術野が得やすくなる，術野を横断するよう
走行し, 内頚静脈前縁で内頚静脈に灌流する顔面静脈 (Fig. 5 lower)は,さまざまなネットワークを形成しているた め, 無暗な鈍的剝離操作をせず, バイポーラ電気メスでの 丁寧な凝固・切離や, 結紮処理操作が必要となる.

内頚静脈を後方に牽引儿, 頚動脈鞘内の䅡神経ワナを確 認し，それを上方にたどれば舌下神経本幹が現れてくる が, 先にも述べたとおり, 直接損傷を避けるべく, 十分下 方より頚神経ワナを確保し，それを上方に辿ることに留意 している. 通常, 舌下神経は C3 レベルの上縁で内・外頚 動脈を横断しており，この術野でもほぼ真ん中で確認でき る(Fig. 6 upper)。また, 内頚静脈近傍を走行する副神経 が，本症例においては内䅡静脈の内側を走行していたがこ の時点で確認でき, 内頚動脈は $\mathrm{C} 1$ レベルより上方まで露 出されている.

上記操作の後, $0.5 \%$ キシロカイン $0.3 \mathrm{cc}$ で頝動脈洞ブ ロックし, ヘパリンナトリウム 5,000 単位, チオペンター ルナトリウム $100 \mathrm{mg}$ を静脈注射後, ACT が 250-350 程 度であることを確認してから, 動脈瘤用のテンポラリーク リップで外䅡動脈抒よびその分枝 (本症例では上甲状腺動 脈, 舌動脈, 顔面動脈)を, また, パーマネントクリップ で内・外澒動脈を，総澒動脈においては，ブルドッグ鉗子 を用いて血流を遮断する.

ついで, 総頚動脈から内頝動脈にかけてスピッツメスで 


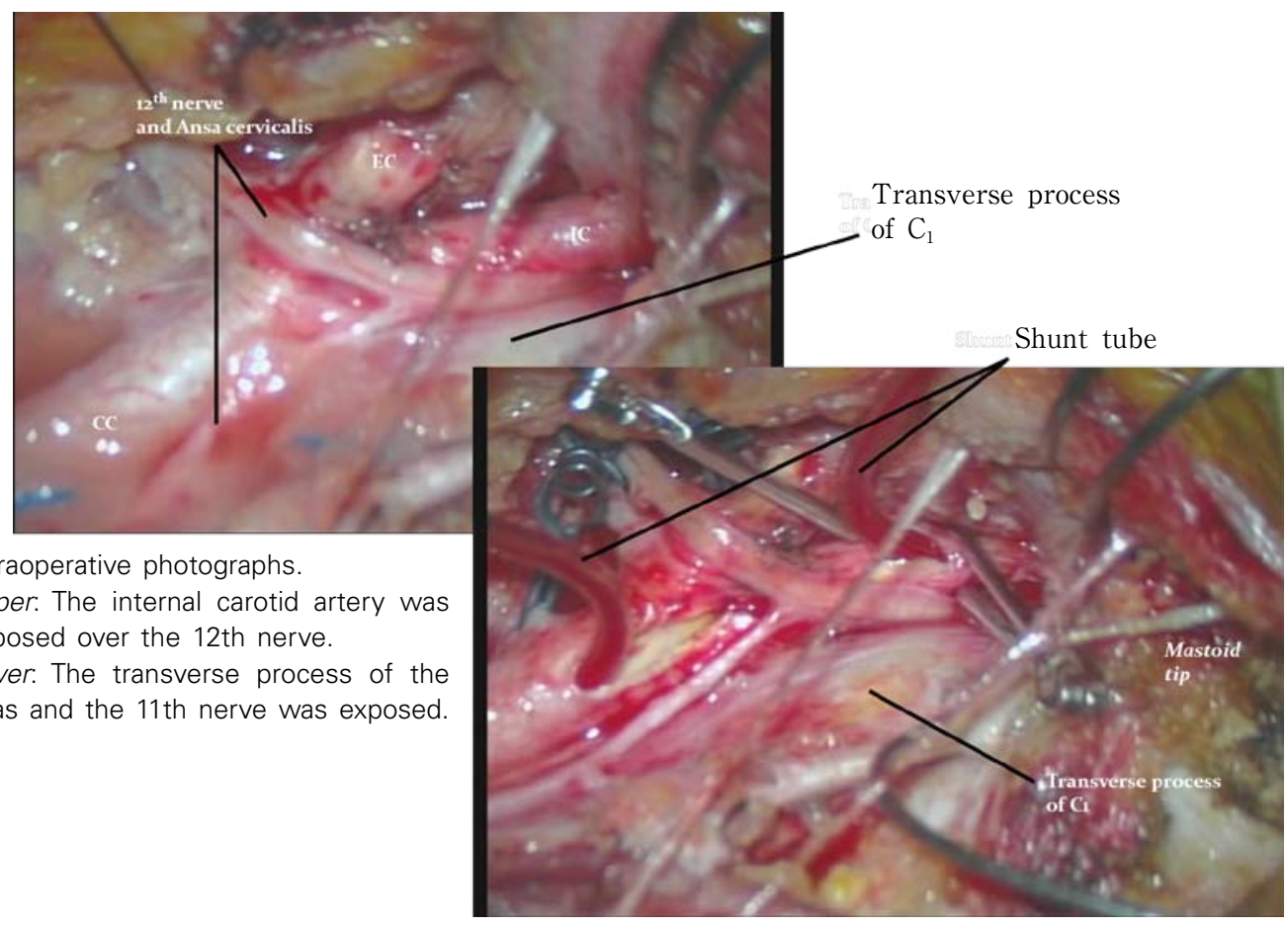

Fig. 6 Intraoperative photographs. upper: The internal carotid artery was exposed over the 12th nerve.

lower. The transverse process of the atlas and the 11 th nerve was exposed

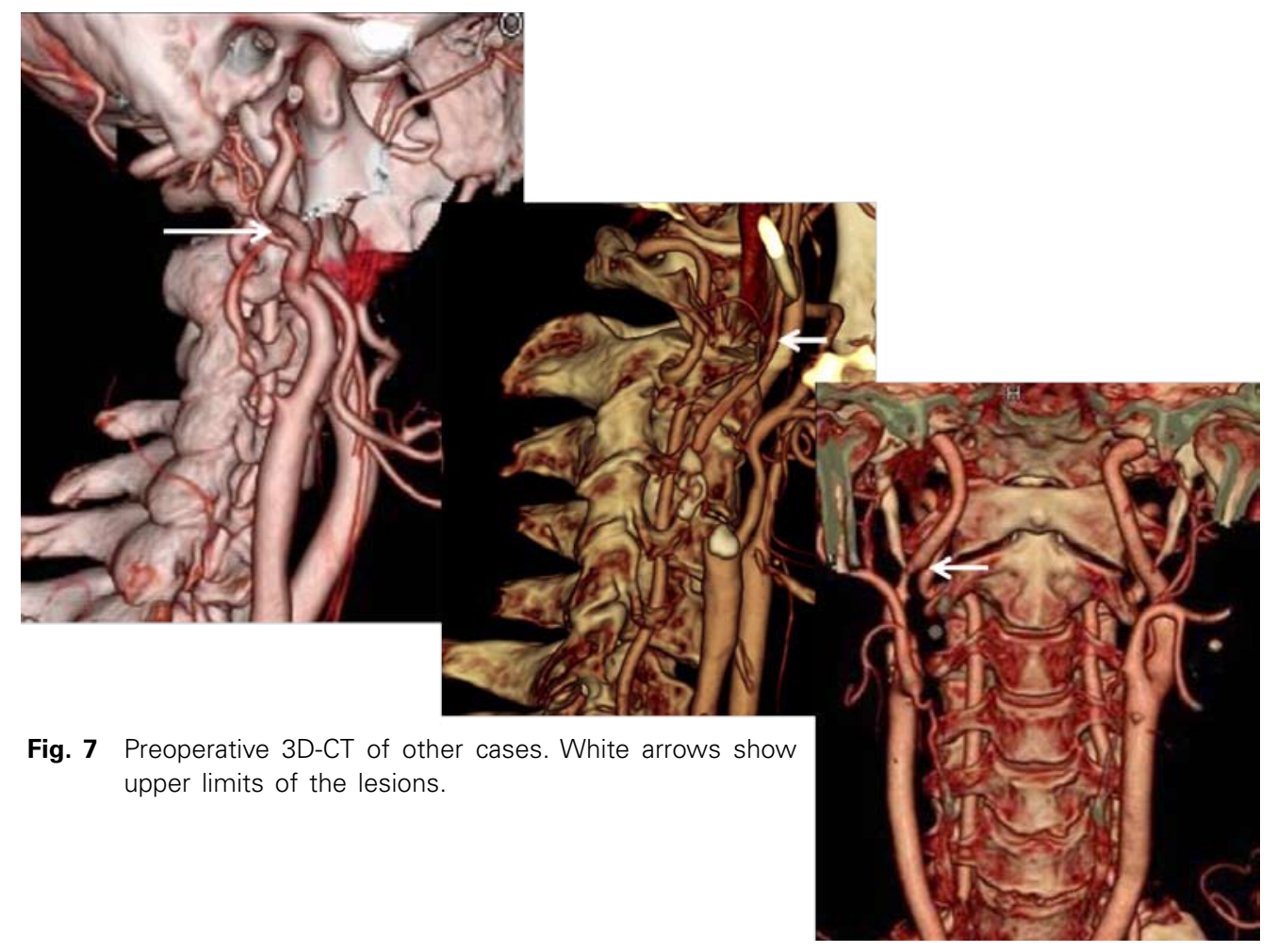

切開後, シャントチューブ (当施設では Pruitt-Inahara Carotid shunt with T-Port $8 \mathrm{~F} も し く は 9 F$ を使用. 本症 例では $8 \mathrm{~F}$ を使用)を挿入 (Fig. 6 lower) し, 剥離子と鑷子 を用いてプラークを剥離したのち, 血管内腔をへパリン生
理食塩水で洗浄しながら, 鑷子でプラーク周囲内膜をトリ ミングする．断端処理はマイクロハサミを用いて鋭的に 行っている. 縫合は 7-0 プロリン糸を用い, 動脈切開の両 端へstay suture を置き, それらを始点として両端から縫 
合していく.シャントチューブ抜去後，両側の糸を縫合し， 外頝動脈およびその分枝, 内頚動脈の順に遮断解除する. 最後に総澒動脈の遮断解除を行うが, この際, 内澒動脈を 1-2 秒ほど徒手的に圧迫し, 血管内微小血栓を外頚動脈側 に誘導させたのち，徒手圧迫を解除している.

すべての遮断解除後, 縫合部を観察し, 止血が確実に確 認できれば，フィブリン糊を貼付し，マイクロ操作を終了 とする．以降は，3-0 モノフィラメント吸収糸を用いて， 頚動脈鞘，胸鎖乳突筋筋膜を単結節縫合，真皮を 5-0 モ) フィラメント吸収糸で埋没縫合, 最後に表皮をステープ ラーで固定して，閉創とする.

\section{結果}

2006 年より 2011 年の間に, 病変が $\mathrm{C} 1$ レベルまたはそ の付近にまでおよぶ「超」高位病変 4 症例に対し本アプ ローチを施行．術中 SEP モニターによる判断を行い，本 症例を含む 2 例にシャントチューブを使用した．他 3 例の 術前写真を Fig. 7 に示す.いずれの症例においても虚血 および脳神経症状などの合併症をみなかった。

\section{考察}

最近, 高齢者や高位病変の患者はいわゆるハイリスク症 例とされ，血管内治療の適応となることが多くなってきて いる ${ }^{11)}$ 。これまでの高位病変に対するアプローチとして は, 経鼻挿管, 顎二腹筋切断, 後頭動脈切断, 下顎角の切 除，顎関節の脱臼処置などの工夫が報告されており ${ }^{24412)}$, その他の手法としては, 頚神経ワナの切断や頚動脈背面一 のガーゼ挿入による内頚動脈の回旋挙上なども報告されて いるが8), われわれのアプローチ法では, 高位病変の露出 に際し，胸鎖乳突筋の前縁で同筋付着部である乳様突起に 向かって深澒筋膜を上方に十分剝離していくことをポイン トとしている.

この上方剝離に関しては, 下方に比すと筋膜付着が格段 に強固であることから，一般的には剥離に難渋するものと 暍念されるが, その理由としては深頚筋膜が, 上方におい ては, 下顎底全体から乳様突起, 後頭骨上項線に掛けて骨 膜と融合していくという解剖学的特徵による. また下顎角 と胸鎖乳突筋前縁との間で，その融合は特に強固とされて いるが3)，マイクロハサミなどを用いて，丁寧に鋭的剝離 していけば, 特に困難を要する操作ではない.

さらに，下顎骨と乳様突起との間にある耳下腺は耳下腺 筋膜 (深澒筋膜浅葉の続き)で覆われているため, 胸鎖乳突 筋前縁での筋膜上方剥離の際, 耳下腺筋膜を前方に翻転す ることで耳下腺ならびに耳下腺内部を貫く顔面神経および その末梢枝を筋膜そのもので保護することができ, 術中操 作による損傷を極力防ぐことができる.
このように, 頚部の膜構造を理解した解剖に基づく層ご との丁寧な鋭的剝離を行うことで, 侵襲性が少なく, かつ 安全に C1 レベル以上までの高位病変の露出が遂行可能と なる.

\section{結 語}

病変がC1 レベルにまでおよぶ「超」高位病変に対する アプローチでは, 十分な head rotationを行い, 従来の方 法よりさらに後方からの術野の確保が重要であり, また, 頝部の膜構造を理解した正確な解剖に基づく層ごとの鋭的 剥離が重要であると考える.

\section{文献}

1) Barnet HJ, Taylor DW, Eliasziw M, et al: Benefit of carotid endarterectomy in patients with symptomatic moderate or severe stenosis. N Engl J Med 339: 14151425,1998

2) Batzdorf U, Gregorius FK: Surgical exposure of the high cervical carotid artery: experimental study and review. Neurosurgery 13: 657-661, 1984

3) Berkovitz Barry KB: GRAY'S Anatomy, Thirty-ninth edition, Churchill Livingstone Elsevier, Spain, 2005, pp541-543

4) Dichtel WJ, Miller RH, Feliciano DV, et al: Lateral mandibulotomy: a technique of exposure for penetrating injury of the internal carotid artery at the base of the skull. Laryngoscope 94: 1140-1144, 1984

5）遠藤俊郎, 林 央周, 平島 豊: シャントシステムを用い ない CEA. No-Shinkei-Geka 29: 605-615, 2001

6) European Carotid Surgery trialists' Collaborative Group: Randomised trial of endarterectomy for recently symptomatic carotid stenosis: final results of the MRC European Carotid Surgery Trial (ECST). Lancet 351: 13791387, 1998

7) Executive committee for the Asymtomatic Carotid Atherosclerosis Study: Endarterectomy for asymptomatic carotid artery stenosis. JAMA 273: 1424-1428, 1995

8）林 央周, 堀恵美子, 秋岡直樹：高位澒動脈狭窄病変に対 する頚動脈血栓内膜剝離術の問題点と手術手技，脳卒中の 外科 36: 163-167, 2006

9) MRC Asymtomatic Carotid Surgery Trial (ACST) Collaborative Group: Prevention of disabling and fatal strokes by successful carotid endarterectomy in patients without recent neurological symptoms: randomized controlled traial. Lancet 363: 1494-1502, 2001

10) North American Symptomatic Carotid Endarterectomy Trial Collaborators: Beneficial effect of carotid endarterectomy in symptomatic patients with high-grade carotid stenosis. N Engl J Med 325: 445-453, 1991

11）坂井信幸：経皮的血管形成術(PTA，ステントを含む)。小 林祥泰(監修)：脳卒中ナビゲーター, メディカルレビュー 社, 東京, 2002, pp274-277

12) Yamamoto I, Ikeda A, Shimoda M, et al: Surgical treatment of extracranial distal internal carotid artery dissecting aneurysm. Neurol Med Chir (Tokyo) 32: 21-27, 1992 